\title{
Preliminary Analytical Study of Vajigandhadi Tailam - An Ayurvedic Polyherbal Formulation
}

\author{
Dr. Gopikrishna.A.S \\ 3rd year PG scholar, Department of Kayachikitsa \\ Amrita School of Ayurveda, Kollam, Kerala
}

\author{
Dr. Krishnakumar.K \\ Dr. James Chacko \\ Co-guide / Associate professor \\ Guide /Associate professor \\ Department of Kayachikitsa \\ Department of Kayachikitsa \\ Amrita School of Ayurveda, Kollam, Kerala \\ Amrita School of Ayurveda, Kollam, Kerala
}

\begin{abstract}
Vajigandhadi eranda tailam is a polyherbal formulation mentioned in the classical text Yogaratnakara. It is a yoga which is not much popular in common practice. It is mainly indicated in the clinical condition Gridhrasi. It is a taila preparation containing 12 drugs vajigandha, bala ,vilwa, kasmari, tarkari, patala, dunduka,saliparni, prsniparni, brhati, kantakari and, gokshura. with eranda taila as base.
\end{abstract}

Quality is the totality of features and characteristics of product of service that bear on its ability to satisfy a given need.

If an herbal remedy is effective, quality assurance is needed to ensure that the product has the expected effects. Even in the absence of data on efficacy, quality assurance is important, as quality is a critical determinant as well.

Quality of a product is a very hot topic now a days, and especially in the pharmaceutical industry. The segment of herbal medicinal products is of no exception. Indeed, the regulatory authorities have paid special attention to quality in this particular industry, due to the high risk of damage to life and health of patients possible, and developed many guidelines to insure a sufficient level of quality.

9 peaks are obtained in hptlc of vajigandhadi eranda tailam with one major peak with RF value 0.71. This study is sufficient enough to show that how much quality is ensured by the product.

Keywords: Vajigandhadi eranda tailam, gridhrasi, sciatica, chromatography

\section{INTRODUCTION}

Ayurveda is the ancient Indian system of natural and holistic medicine. When translated from Sanskrit, Ayurveda means "the science of life" (the Sanskrit root ayur means "longevity" or "life" and veda means "science"). Ayurvedic medicine uses a variety of products and practices. Ayurvedic products are made either of herbs only or a combination of herbs, metals, minerals, or other materials in an Ayurvedic practice called rasa shastra. Some of these products may be harmful if used improperly or without the direction of a trained practitioner.

Ayurveda represents the ancient Indian art of healing. In it, the human body is not considered just as a mass of organs, systems and tissues; but the complex mechanism' of myriad functions taking place, both at physical and mental level, are evaluated and described. In existence for thousands of years now, the basic principle of Ayurveda has managed to remain the same. The human body is more complex than any other form of life as on date. Purusha - the human body is the aggregate of 25 elements, together with Atma - the spirit or soul. In order to explain the functional complexity of human body, Ayurveda has propounded a few basic doctrines. These doctrines visualize the functional units of the body to be formed by three Dosha (humours), seven Dhatu (tissues) and Mala (metabolic end products) which are in equilibrium.

The treatment in Ayurveda is decided based on the basis of dosha aggravation and level of dhatu and mala vitiation. There are various kalpanas for administration of medicines in Ayurveda like swarasa 


\section{Dr. Gopikrishna.A.S et al.}

kalpana, churna kalpana, kwatha kalpana, sneha kalpana, gutika kalpana, avaleha kalpana, arishtasava kalpana etc,. Vajigandhadi tailam ${ }^{1}$ is a medicine prepared in the form of taila kalpana. It is mentioned in Yogaratnakara and is not a common formulation among clinical practitioners of Ayurveda. Its indication is only for the vataroga-gridhrasi for panam and vasti. Gridhrasi ${ }^{2}$ is correlated with the modern clinical condition 'Sciatica'. Sciatica ${ }^{3}$ is a name given to pain in the area of distribution of the sciatic nerve (L4 to S3), which is commonly felt in the buttock and over the posterolateral aspects of the leg.

Absence of statutory standards and controls of the authorities made it easier to procure license for manufacturing and sale of Ayurveda medicines. On one hand, one could see an increase in the turnover of Ayurveda industries, the other side, number of generic Ayurveda medicines disappeared from the market or came in short supply. Ayurveda was written thousands years back using the parameters of those time, which may appear quite crude in comparison to the modern age scientific parameters. We live in an era when sophisticated and advanced technologies are easily available to us. Ayurveda drug manufacturers should make use of these technologies in the further development of the existing formulations.

Even though specific parameters are available in the Ayurvedic classics it is necessary to evaluate their safety and efficacy through modern parameters. Keeping this in view, the CCRAS committee has set specific criteria for specific dosage forms ${ }^{4}$. Here an attempt has been made to study vajigandhadi tailam analytically and to develop fingerprints of High-Performance Thin Layer Chromatography study (HPTLC).

\section{MATERials AND MeTHODS}

Collection of raw drugs: All the individual drugs of the compound drugs of the formulation Vajigandhadi tailam were bought from the local markets of Changanacherry, Kottayam Dist of kerala and they were authenticated in the department of Dravyaguna, Amrita School of Ayurveda, Kollam, Kerala.

Pharmaceutical study: Vajigandhadi tailam was prepared with the ratio mentioned in Table 1 at Department of Rasashastra and Bhaishajya Kalpana, Amrita School Of Ayurveda, Kollam, Kerala.

\section{Method of Preparation}

After the identification of the drug, drugs were washed and dried properly. Since kasaya dravyas and kalka dravyas are not mentioned separately the same drugs in the proportion mentioned as below is to be used. The drugs Aswagandha, Bala, Vilwam and Dasamoolam(10 drugs as 1part)are taken in the same proportion for kalkam and kwatham. The ingredients of vajigandhadi tailam is in the below table

\begin{tabular}{|l|l|l|}
\hline Sl.no: & DRAVYA & BOTANICAL NAME \\
\hline 1 & ASHWAGANDAM & Withania somnifera Linn. \\
\hline 2 & BALA & Sida cordifolia Linn. \\
\hline 3 & VILWA & Aegel marmelos Linn. \\
\hline 4 & AGNIMANTHA & Premna serratifolia Linn \\
\hline 5 & SYONAKA & Oroxylum indicum Linn. \\
\hline 6 & KASHMARI & Gmelina arborea Linn. \\
\hline 7 & PATALA & Stereospermum sauvealens \\
\hline 8 & KANTAKARI & Solanum xanthocarpum \\
\hline 9 & BRIHATI & Solanum indicum linn \\
\hline 10 & SALAPARNI & Pseudarthria viscid Linn. \\
\hline 11 & PRISHNIPARNI & Desmodium gangeticum Linn. \\
\hline 12 & GOKSHURAM & Tribulus terrestris Linn. \\
\hline 13 & ERANDA TAILA & Ricinus communis \\
\hline
\end{tabular}

The kalkam, tailam and kwatham for preparation of Vajigandhadi tailam were taken in the proportion 1: $4: 16$ as per classical reference. ${ }^{5}$

\subsection{Preparation of Kalkam}

For the preparation of kalkam the drugs Aswagandha, Bala, Vilwam and Dasamoolam(10 drugs as lpart)are taken in equal proportion washed, dried and fine powdered. Then it was grinded for half hour using a motorized grinder. 


\subsection{Preparation of Kwatha ${ }^{6}$}

For the preparation of kwatham the drugs Aswagandha, Bala, Vilwam and Dasamoolam(10 drugs as 1part)are taken in equal proportion. To this 8 times water was added and then boiled in low flame to reduce it to $1 / 4^{\text {th }}$ of total water.

\subsection{Tailam}

Shudha eranda tailam available in the market was taken.

The indication of Vajigandhadi tailam is for paanam and vasti. The sneha paakam for vasti and paanam is chikkana (madhyama)paakam.

\subsection{Preparation of Tailam}

As mentioned before the proportion of kalkam, tailam and kwatham taken were 1:4:16. The prepared kalkam and kwatham was kept aside. Sudha eranda tailam was measured and poured into a brass vessel with thick base on medium flame .The kwatham and kalkam was also trasfered into the vessel and the mixture was boiled in medium flame with continuous stirring and monitoring of paakam. The boiling was stopped and the oil was filtered using a washed and dried white filter cloth when chikkana paanam was attained.

\section{Analytical Study}

The Analytical study deals with the physical and chemical evaluation of the given formulation carried out at R\&D unit of Aryavaidya sala Kottakkal. Organoleptic parameters, Physico-chemical analysis were carried out by following standard procedure mentioned in Ayurvedic Pharmacopeia of India. Various organoleptical parameters of the formulation, such as colour, odour and taste of the tailam were recorded. In physical evaluation the tailam was found to be light brown in colour,acid value is 2.5, with an iodine value of 91.09 , saponification value of 189.76 and refractive index of 1.472 were determined

\subsection{Heavy Metal Analysis}

The pharmacological laboratary for indian medicine, Ghaziabad have set a standards for the presence of various heavy metal contents in various ayurvedic medicine. This taila had all the heavy metals below detectable limits.(table no: 1 )

\subsection{High Performance Thin Layer Chromatography (HPTLC)}

Studies were carried out with solvent system toluene:ethyl acetate: Formic acid: Methanol (7:3:1:0.5)). CAMAG HPTLC system equipped with a sample applicator Linomat 5 sample applicator was used for application of samples.

CAMAG TLC Scanner 3, Reprostar and Wincats 4.02 were used for scanning the plates. CAMAG twin through glass chamber was used for developing the plates. The sample Vajiganghadi tailam (10 $\mathrm{ml}$ ) was extracted with $10 \mathrm{ml}$ methanoland spotted as as 5 microlitres for $1 \mathrm{hr}$. under reflux.

Theplates were developed in mobile phase of Toluene: Ethyl acetate:Formic acid:Methanol( 7:5:1:0.5) and scanned at $254 \mathrm{~nm} .9$ peaks are obtained in hptlc of vajigandhadi eranda tailam with one major peak with $R F$ value 0.71 .

TEST RESULTS (Table 1)

\begin{tabular}{|l|l|l|l|l|}
\hline SL NO & TEST PARAMETER & UNIT & RESULT & STANDARD \\
\hline O1 & Description & - & Light brown oil & - \\
\hline 02 & LOD & $\%$ W/W & 0.41 & - \\
\hline 03 & ACID VALUE & - & 2.5 & - \\
\hline 04 & IODINE VALUE & & 91.09 & \\
\hline 05 & SAPONIFICATION VALUE & & 189.76 & \\
\hline 06 & REFRACTIVE INDEX & & 1.472 & \\
\hline 07 & HEAVY METAL CONTENT & & & \\
& a) LEAD & Ppm & BDL & NMT 10 \\
& b) ARSENIC & Ppm & BDL & NMT 3 \\
& c) CADMIUM & Ppm & BDL & BDL 3 \\
& d) MERCURY & Ppm & NMT 1 \\
\hline
\end{tabular}




\section{HPTLC ANALYSIS OF VAJIGANDHADI TAILAM}

\section{A. Sample Details}

01. Vajigandhadi tailam (Vasti \& Pana pakam)

Ref: Yogaratnakaram

\section{B. HPTLC Conditions}

01. $10 \mathrm{ml}$ Vajigandhadi tailam sample is extracted with $10 \mathrm{ml}$ methanol and spotted as 5 microlitre.

\section{Stationary Phase}

Merk, 1.05554.0007, TLC Silica gel $60 \mathrm{~F}_{254}, 10 \times 10 \mathrm{~cm}$ Aluminium sheet.

\section{Mobile Phase}

Toluene: Ethyl acetate: Formic acid: Methanol (7:5:1:0.5)

E. Development

CAMAG 10 x $10 \mathrm{~cm}$ Twin trough chamber.

\section{F. HPTLC Instrumentation}

CAMAG Linomat 5, CAMAG TLC Scanner 3, CAMAG Reprostar 3

\section{G. Derivatization}

$10 \%$ sulphuric acid reagent

H. Results

01. Overview Graph of Vajigandhadi Tailam Sample At 254nm

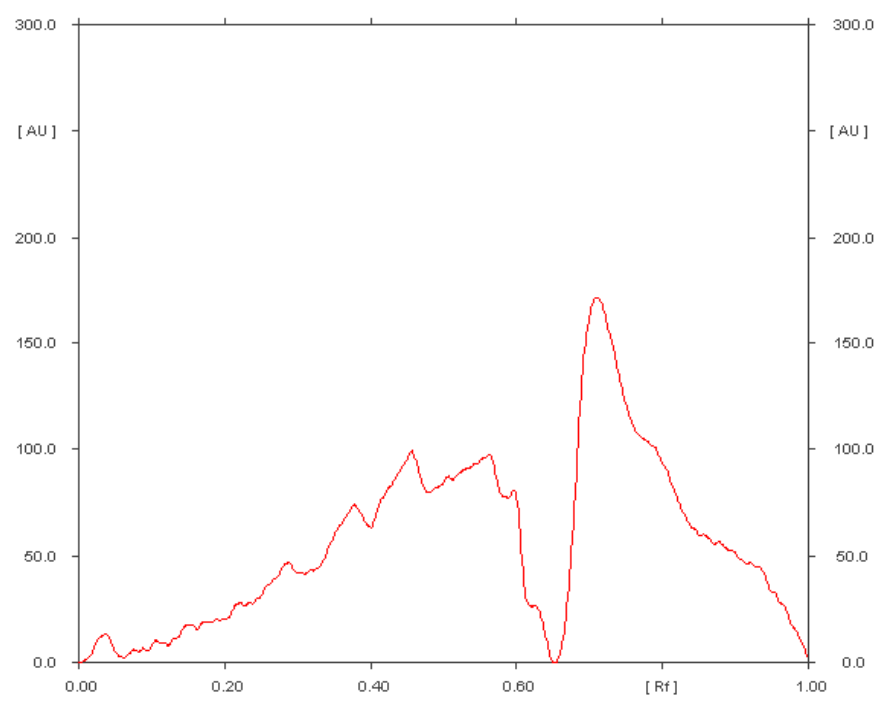

02. Overview Graph of Vajigandhadi Tailam Sample AT 366nm

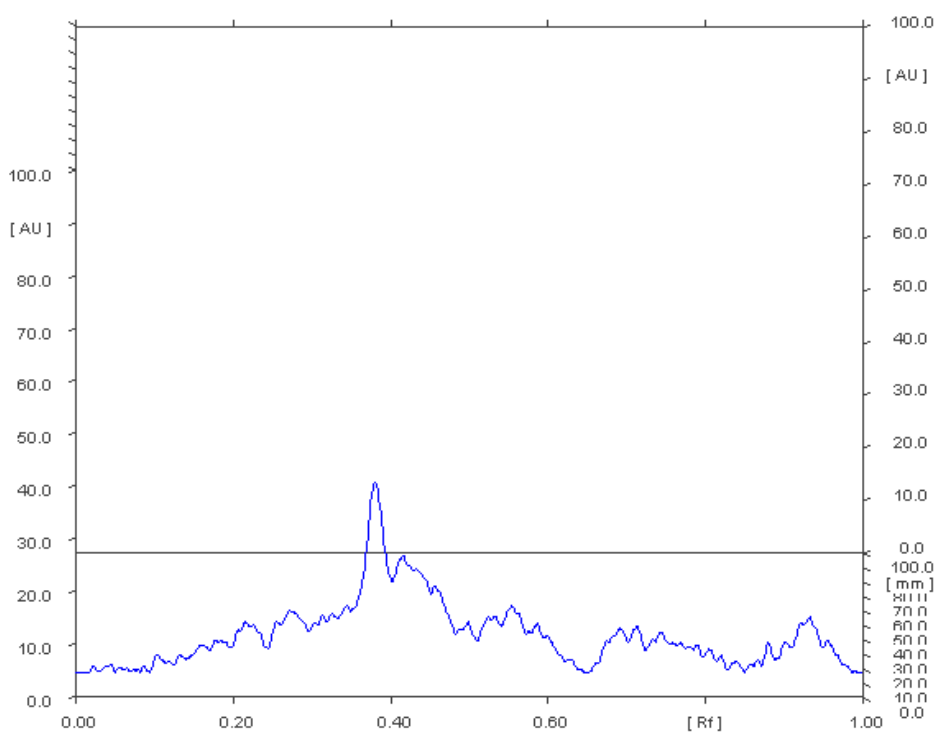


03. TLC Plate Views of Vajigandhadi Tailam Sample

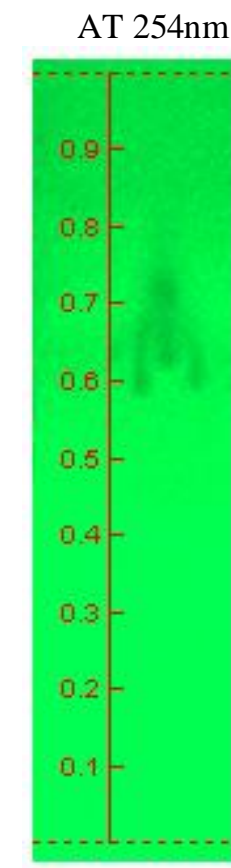

Derivatization

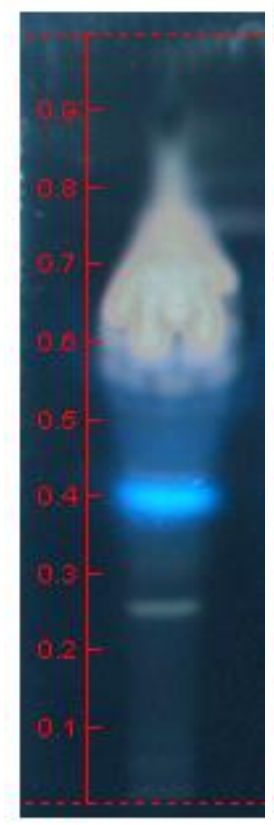

AT 366nm

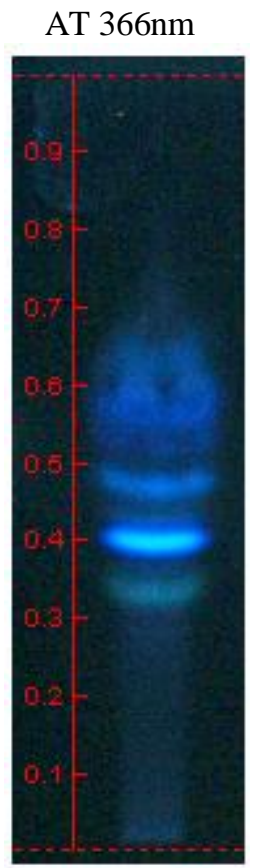

Derivatization

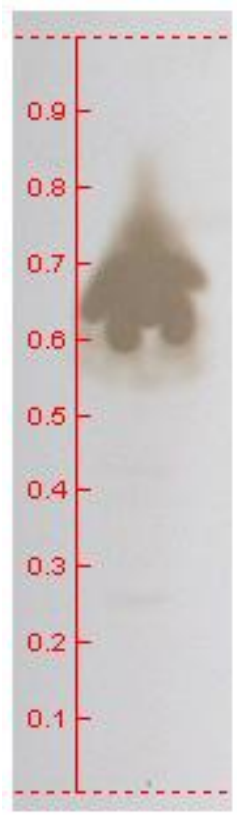

AT White Light

04. Area\&Peaks of Vajigandhadi Tailam Sample AT 254nm

\begin{tabular}{|l|l|}
\hline Vajigandhadi tailam Peak no & Vajigandhadi tailam Area(AU) \\
\hline 1 & 249.9 \\
2 & 53.9 \\
3 & 186.8 \\
4 & 486.4 \\
5 & 808.6 \\
6 & 672.4 \\
7 & 396.2 \\
8 & 11099.5 \\
9 & 273.4 \\
\hline
\end{tabular}

Vajigandhadi Tailam Sample

01. TOTAL PEAK NO - 09

02. TOTAL AREA - $14227.1(\mathrm{AU})$ 
05. Major Peak Details of Vajigandhadi Tailam Sample AT 254nm

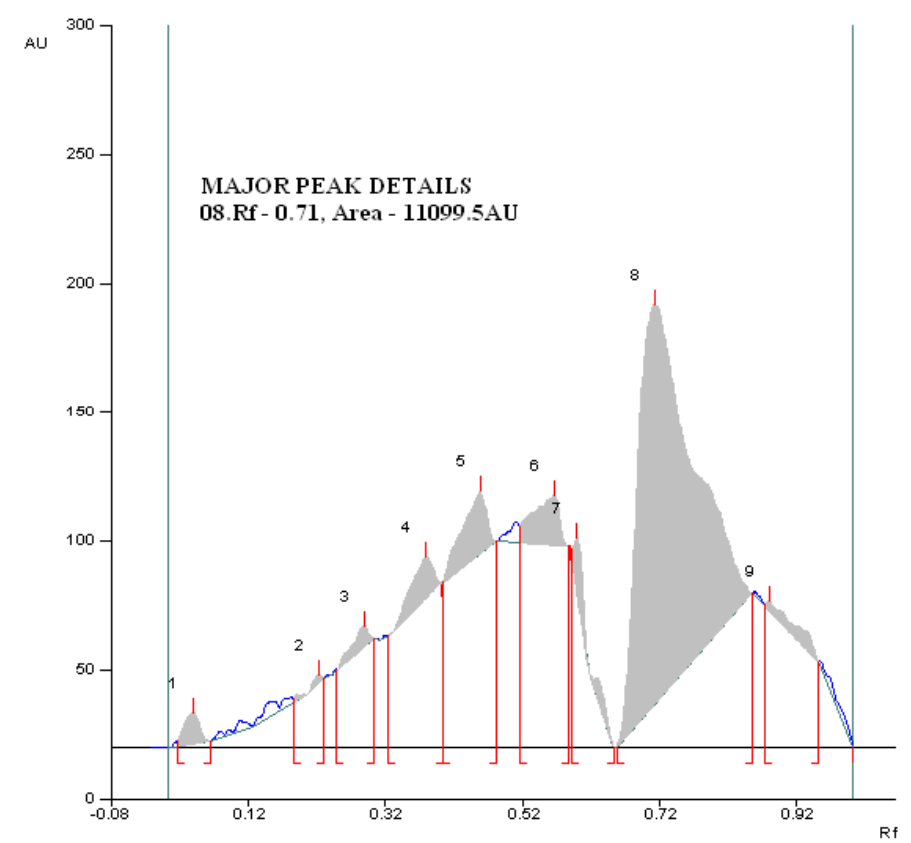

\section{DisCUSSION}

Herbal medicines are generally considered comparably safer than synthetic drugs. While this may be probably correct, case reports show that severe side effects and relevant interactions with other drugs can occur. Lack of regulatory standards regarding the efficacy and safety of herbal products did not arouse much concern in the past, as these products were often perceived as so safe that even if they were ineffective, little harm resulted. However, the situation is changing now and there is increasing body of literature on th side effects and interactions of herbal medicines. Besides the direct risks of adverse effects and drug interactions there is an indirect risk that an herbal remedy without demonstrated efficacy may compromise, delay, or replace an effective form of conventional treatment.

pH shows Vajigandhadi tailam is acidic in nature. Heavy metal content are also not exceeding the safe limits.

\section{CONCLUSION}

Following good evaluation practice in herbal medicine is an effective strategy in achieving health for all. Good evaluation practice is the right evaluation at the right time, with the right investigators conducted with the highest ethical standards.

A strong commitment is required from the research community to follow good evaluation practice and to provide quality information about herbal medicine to the public and health professionals. rigorous quality research is needed to support the claims of herbal medicine for the benefit of mankind. Today, this evaluation process is contributed from the collective technical expertise in several diverse areas, including ethnobotany and ethopharmacology, classical botanical pharmacognosy, natural products chemistry, phytochemistry, analytical pharmacognosy, phytotherapy and clinical pharmacy.

Achieving complete and wholesome standardization of evaluation of herbal formulations is the need of the hour and its implementation will be a historic leap towards India's health security.

\section{REFERENCE}

[1] Vaidya Sri Lakshmipathi sashtri-Yogarathnakara-Vidyothini Hindi Teeka.Edited by Bhishagratna Brahmasankar Sastri,Chaukamba publications, Varanasi, $7^{\text {th }}$ Edition 1999 , Vatavyadhi chikita pg.no: 522

[2] Prof. K.R.Srikanta murthy Bhavaprakasha of Bhavamishra Chaukamba Krishnadas Academy Varanasi Vol.2 $4^{\text {th }}$ Edition 2009, Madhya kanda 24/129-134 Pg.no:331.

[3] Harrison's principles of internal medicine. Anthony S.Fauci editors.\$ Mc Graw hill Publication. $17^{\text {th }}$ ed. Vol 1, 2013.Page No.2155. 
[4] Safety/toxicity study report of some Ayurvedic drugs by Central council for research in Ayurveda \&Siddha, Department of Ayush, Ministry of health\& family welfare, NewDelhi, 2009 Edition.

[5] Sarangadhara samhita of sarangadaracharya, translated by Dr.Himasagara Chandran Murthy,Chowkhamba Sanskrit Series office Varanasi 2010 Edition Madhyama khandam 9/ 1-2, page no: 199 .

[6] Sarangadhara samhita of sarangadaracharya, translated by Dr.Himasagara Chandran Murthy,Chowkhamba Sanskrit Series office Varanasi 2010 Edition Madhyama khandam 9/ 3, page no: 199 .

\section{AUTHORS' BIOGRAPHY}

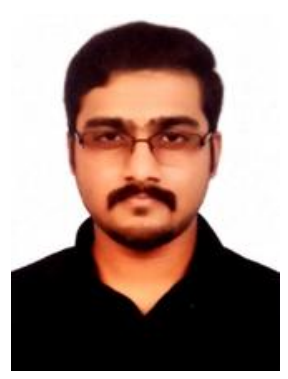

Dr. Gopikrishna.A.S., currently doing post-graduation studies in the Department of Kayachikitsa, Amrita School of Ayurveda. He pursued his Bachelor of Ayurvedic Medicine \& Surgery (BAMS) in 2013 under University of Kerala from Pankajakasturi Ayurveda Medical College, Thiruvanandapuram.

He secured 1st prize in Poster presentation competition on Drug induced liver disorders and role of Ayurveda, at VPSV Kottakal Ayurveda College 29th July 2015. He has also presented a paper titled "Role of Nithya Rasayana In Graceful Ageing" in Global Ayurveda Fest - 2016 on January 31, 2016.

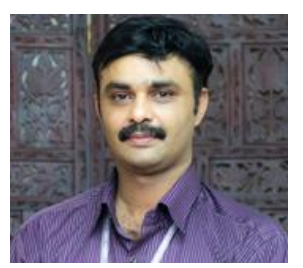

Dr. Krishna Kumar K., currently serves as Associate Professor in the Department of Kayachikitsa, Amrita School of Ayurveda. He pursued his Bachelor of Ayurvedic Medicine \& Surgery (BAMS) in 2002 from SreeChandrasekharendraSaraswathy Ayurveda Mahavidhyalaya, and M.D. (Kayachikitsa) in 2006 from RGUHS, Bangalore. He started his teaching career as an Assistant Professor in the department of Kayachikitsa in Amrita School of Ayurveda. He is a recognised guide for PG studies in Kayachikitsa in Amrita School of Ayurveda. He has also presented two scientific papers in Global Ayurveda Congress held at Trivandrum and Kochi. He has done extensive research work in Diabetes mellitus and psoriasis, in collaboration with NMPB and SMPB. He has taken several classes for the public in relation with medical culture and marketing techniques of Ayurveda medicinal plants and is also author of various national and international publications. He is taking responsibility as President of Ayurveda Medical Association of India since 2013.

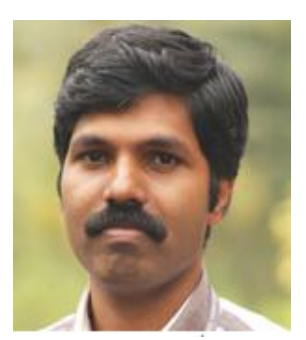

Dr. James Chacko, currently serves as Associate Professor in the department of Kayachikitsa, Amrita School of Ayurveda. He pursued his Bachelor of Ayurvedic Medicine \& Surgery (BAMS) in 2002 from RGUHS, Bangalore and M.D. (Kayachikitsa) in 2006 from RGUHS, Bangalore. He started his teaching career from Nangeli Ayurveda Medical College, Kothamangalam in the year 2006 (October) as an Assistant Professor. In October 2011, Dr. James completed his $\mathrm{Ph} . D$. from the department of Kayachikitsa, Tilak Ayurveda Mahavidhy alaya, Pune. He is a recognized guide for PG and PhD students in Kayachikitsa at Amrita School of Ayurveda. He has also presented a scientific paper in Global Autisam Seminar held at Bangalore in 2011 and has also authored various national and international publications. 